\title{
Local Development Stakeholders and the European Model: Learning the LEADER Approach in the New Member States
}

\author{
MARIE-CLAUDE MAUREL* \\ CEFRES, Prague
}

\begin{abstract}
The introduction of a new model of territorial development based on a bottom-up approach appears to be an entirely new process in the formerly communist countries of Central Europe. However, the ongoing process of Europeanisation in these countries is acting as a catalyst for the transmission of this model of endogenous development, a model whose principles are to highlight the specific advantages of each territory and to foster the initiatives taken by decentralised actors. 'Territorial governance' is a notion that sums up these new patterns of public policies that are in keeping with a multi-level environment. At the crossroads of European and national policies with bottom-up initiatives, taken by local stakeholders (local representatives, project managers, etc.), new patterns in territorial resetting are also appearing as part of the change in territorial governance. How does such a transfer of model take place and what effects does it imply? This paper is aimed at analysing the reception of this European model of local development by local actors and their ability for social learning.

Keywords: local development, LEADER approach, territorial governance, social learning

Sociologický časopis/Czech Sociological Review, 2008, Vol. 44, No. 3: 511-529
\end{abstract}

\section{Introduction}

The implementation of a new European policy based on integrated rural development is an entirely new experiment in the former communist countries of Central Europe. This article attempts to explore the conditions and the context in which rural development policy is being transferred from former member states to new ones, and its effects on their political systems. To examine this issue, we can look at the European Union's 'LEADER' programme (an acronym of Liaisons Entre Actions de Développement de l'Economie Rurale). The ongoing process of Europeanisation is acting as a catalyst for the transmission of a new model of endogenous development in rural areas of the new member states. In the framework of implementing the LEADER approach, European Union rural development funding aims to provide the conditions for innovative actions and projects to emerge. The

* Direct all correspondence to: Marie-Claude Maurel, CEFRES, Vyšehradská 49, 12800 Prague 2, Czech Republic, e-mail: maurel@cefres.cz.

(C) Sociologický ústav AV ČR, v.v.i., Praha 2008 
LEADER programme provides a current perspective for introducing a new type of bottom-up action based on the engagement of endogenous material and nonmaterial resources to produce sustainable local development. Two features of the LEADER programme will be examined. The first is the experimental nature of the EU LEADER programme, intended as a 'pan-EU laboratory of rural development' [Ray 2000]; the second is its participatory nature as a learning social process likely to introduce a new mode of governance. These two characteristics have possible specific implications for transforming societies.

The article covers the first two years (2004-2006) of implementation of the new LEADER programme in new member states ${ }^{1}$. It attempts to assess the first effects of its implementation, looking at the responsiveness of rural communities in three new member states, Hungary, Poland, and the Czech Republic. Apart from the relevant academic literature, the article is based on official national sources and a field research survey. It is cross-national comparative work that takes into account national and local variations in order to highlight similarities and differences and thereby contribute to the ongoing process of Europeanisation of these countries in a widening EU. It offers a range of thematic viewpoints on the modes and consequences of the transfer of the institutional model and development policies.

\section{How to transfer the European model to the new member states}

\section{Drawing up the rural development paradigm}

In varying ways and at varying speeds, the EU's rural development policy has undergone great changes since the late 1980s [Nemes 2005]. Rural development is becoming the new paradigm for politics, socio-economic practices and the social sciences. There has been a shift away from the primacy of agricultural development based on modernising structures and intensifying and specialising production (the 'productivist' model) towards a vision of integrated, sustainable

\footnotetext{
${ }^{1}$ The research project on 'Local Actors Facing the European Model. A Comparison of France, Hungary, Poland, and the Czech Republic' (PICS No. 3723, CNRS, 2006-2009) began in 2006 and is based on the continuous observation since that date of the transformations occurring in selected local communities. Field-work studies were designed for data collection. Several Local Action Groups (LAGs) were selected in Hungary (Baranya county), Poland (Małopolska and Opole voivodeships), and the Czech Republic (the regions of Southern Bohemia and Southern Moravia). The task was to understand how stakeholders coped with a new situation that involved strategic choices, and then to follow the achievement of their plans in the context of EU integration. Each observed location was the subject of a separate study, each using the same methodology (interview guidelines), and applying a comparative approach. Set in their geographic context, these studies examined both the effects due to a place's integration in a specific national system and the effects proper to that place (given its social history).
} 
rural development. In 1988, the debate over a new Structural Policy intervention for the EU resulted in the drawing up of a territorial, endogenous model for rural development. The principles of this new approach were reaffirmed at the Cork Conference in 1996: 'Rural development policy must be multi-disciplinary in concept and multi-sectoral in application, with a clear territorial dimension' [Commission of the European Communities 1996]. This marked a clear turning point in the conceptual approach, with new ways of thinking about and promoting territorial development. Territorial development policies can be understood as development support policies that focus on promoting new territories on the basis of local community projects. In line with political decentralisation, they involve a trend towards territorialising the Structural Funds that responds to a more localised definition of public issues and how they are to be addressed. This shift from a centralised, exogenous mode of development to a decentralised, endogenous one, based on local initiatives and resources, has taken on various forms in terms of programmes. Of these we here look at the European Union's LEADER programme.

With the 1988 reform, the European Commission acquired the power to introduce its own pilot interventions, 'Community Initiatives', the rural development version of which was LEADER [see Ray 2000]. The new style of intervention involved the design of general guidelines for the use of funds but leaving each country greater room to manoeuvre in its implementation. The LEADER initiative was introduced in the twelve-member EU in 1991 for a three-year period. It took the form of pilot activities intended to stimulate innovative approaches at the local level. The programme was renewed in 1995 with an expanded, five-year version, LEADER II, and then again in 2000, as LEADER+. The novel feature of this integrated approach on a territorial basis is that it stimulates innovative approaches to rural development at the local level through small-scale projects. Local organisations called Local Action Groups (LAG) could apply for LEADER funds by producing a 'business plan' for local development activities. The active participation of public, voluntary and business stakeholders at the local level was promoted in order to strengthen the capacities of local community by involving them.

As a political project, endogenous development is based on well-established principles and an experimental method that can be defined as follows: a territorial approach rather than a sector-based principle; optimum use of local resources so as to maximise the benefits from activities and retain the profits locally; development that targets the needs, capacities and expectations of the local population; participation of local stakeholders in designing and implementing the development strategy (defined in a 'strategic or business plan'), and attempts to enable local communities to manage the conditions and effects of development (experiments in participatory democracy). This is the model hat the older member states have been trying out for nearly twenty years now, and which has been proposed for the new members in the form of a LEADER+ measure, funded by the European Agricultural Guidance and Guarantee Fund (EAGGF) for 
2004-2006. Within the framework of European economic and social cohesion policy, the EAGGF supports rural development and the improvement of agricultural structures (2000-2006). Six new member states have chosen to adopt this measure following LEADER+ principles. Among them are the Czech Republic, Hungary and Poland. Slovakia has not adopted the LEADER programme. The three Baltic States, which are also transition countries, exhibit different features than the Central European countries. The LEADER model is being transferred through an institutional process, the mechanisms of which will be examined below, along with their political and practical effects on the new members' institutions, stakeholders and policies [Bruckmeier 2000]. The introduction of the LEADER+ measure offers local stakeholders a chance to get obtain resources and mobilise their capacities for action.

The questions to look at are: How can the implementation of the new principles of public action proceed by drawing on the experience of older member states? [Halamska 2005] Are the general guiding principles enough to ensure compliance with the original endogenous development model inspiring the LEADER+ measure? What does the implementation of this single EU intervention tell us about rural development policy in each national context? [Kovach 2000] How do local stakeholders appropriate the new approach that relies extensively on local initiative? Are they successful in managing a new method of territorial governance that breaks entirely with earlier practice?

\section{The background to transferring the European model to rural transition societies}

It is important to recall the background to the transfer of the rural development model to the new member states. It is now just over eighteen years that the postcommunist countries of Central Europe have been following a path of socioeconomic transformation. Below only the main features of the restructuring process that occurred in former communist countries (hereafter 'transition societies') will be outlined. During the systemic change, reforms concerned the building of democratic institutions, the shift to the market, as an economic regulation mechanism, and the restoration of private property.

In rural areas once regimented and administered by collective agrarian structures, the transformation process implied both a transformation of socioeconomic functions and a change in the manner of managing local communities [Illner 2003]. The dismantling of the communist regime meant a radical change in the institutional model. Local government reforms launched in 1990 introduced the principles of the Western institutional model, based on political democracy and local autonomy. This model replaced the unified system of public administration, which held a monopoly over state property and financially controlled the budget. Within the local system, coordination and integration were now carried out by local self-government. Recognition of local autonomy made this self-gov- 
ernment the key institution in the management of local affairs. These reforms brought about a genuine process of democratisation. From that point, former officials either withdrew or changed their behaviour, and new political actors stepped forward to take part in the local government. Politically, democratisation and decentralisation have favoured the emergence of new elites likely to lead local governments, and new social stakeholders have appeared on the local scene.

At the same time, new regulation mechanisms of economic activities were introduced with privatisation, for example, the establishment of property rights for all assets. This covered both land and the means of production, particularly in agriculture (the conversion of former collective farms), and also infrastructures and utilities (ownership transferred to municipalities). The recognition of the principle of free enterprise favoured the reorganisation of economic activities among small and medium-sized private enterprises (including foreign capitalowned firms). In the new context of the market economy, rural areas were exposed to the impact of globalisation, which had been retarded by the barriers thrown up by the communist economy. Faced with the challenges of economic competition, rural areas were subjected to the imperative of restructuring economic activities, upgrading infrastructure, training human resources, etc.). This impact accelerated the transition from a mono-functional rural economy to a more diversified one [Kovach 2002].

These political, economic and social changes are subjecting rural areas to an intense and highly selective restructuring process. The transformations going on are many. Unequally endowed with the factors of production, ${ }^{2}$ rural areas were plunged into a new economic environment defined by openness to international trade, the arrival of foreign investors, increasing exchanges and faster circulation of information. The impact of spontaneous market forces on these rural areas varied according to the ability of rural communities to connect to communication and information networks, make good use of their resources, and promote local development projects. These factors are primarily social in nature and concern the flexibility of the population: the educational and training standards of the labour force, the degree of social integration, cultural preferences, entrepreneurship and work conscientiousness. The transformation process does not occur in the same way in all countries and within them in all regions.

These systemic changes reshaped the social pattern: the democratisation of local self-governments, the strengthening of economic stakeholders and new forms of ownership, the revival of civil societies, etc. The principles of economic freedom and responsibility that order the behaviour of individuals or economic entities in a free-market economy help to redefine the role of the stakeholders in society. Within their particular fields of endeavour, these stakeholders got more room for manoeuvre. Depending on the 'social capital' they held, they were bet-

${ }^{2}$ Economic factors include the level of development, the diversity of the pattern of economic activities, and the ratio between declining and growth-potential sectors. 
ter or less well suited to find a place in the new pattern. 'People tend to convert devaluated forms of capital into new, more valuated forms' [Matějů and Vitásková 2006: 497]. Positions changed and roles differed from those played before, although a significant portion of former local elites managed to remain in place. According to local conditions, social relationships moved more or less easily away from the legacy of 'paternalistic' behaviour. The entire local system embarked upon a learning curve for new ways of managing and mobilising local resources. From this point on, deep social changes occurred on the local scene where relatively autonomous stakeholders (local political elites, new entrepreneurs, NGOs, etc.) took up the leadership [Kovach and Kučera 2006]. Local communities were reshaped and entered into economic competition. But it would be wrong to suggest that there is no social capital (defined as a public good) in rural post-communist societies [Matějů and Vitásková 2006: 495]. Even if generalised trust (i.e. the extent to which people trust their fellow citizens), which was destroyed to some extent during the communist period, was hard to restore, the trustworthiness of the institutions of self-government strengthened rapidly. Roughly speaking, these structural changes have created a favourable social context. But we have to mention that some remaining 'negative social capital' could inhibit economic development. In Poland, expanding rural poverty has weakened interpersonal trust (especially in neighbouring relationship) and has pushed individuals towards closer family ties [Maurel and Halamska 2006]. Generally speaking, postcollectivist societies tend to be reluctant to cooperate and act collectively. Other negative legacies inseparable from the communist period are likely to hinder the process. The relative persistence of certain inherited traditions, like bureaucratic control and political centralism, and practices such as bribery and grey economy are burdensome factors [Meyer-Sahling 2007].

\section{Local stakeholders to the test: formulating hypotheses}

Based on the background described above, the following hypotheses are proposed for further elaboration and testing (though not all of them can be empirically addressed in the first stage of this research work). Are the transforming rural societies able to fulfil all the expectations of enforcing the EU-LEADER principles: partnership, subsidiarity, transparency?

First, the implementation of the LEADER programme necessitates the creation of a Local Action Group (LAG) based on a formal partnership involving elected bodies, associations, entrepreneurs or farmers at the community level. How do local stakeholders appropriate the new approach that calls extensively on their initiative? Are they successful in managing the new way of building development strategies that breaks entirely with earlier practice? How can we assess it using different criteria: the number of applications, the quality of the projects, like innovative features, the involvement of stakeholders, and civic participation, etc.? Taking into account the heterogeneity of territorial coverage, what are the 
main factors behind the responsiveness of local communities? Are there more variations between countries or between regions and places in each of them?

Second, the EU-LEADER programme is acting as a catalyst in spreading a new form of territorial governance. This question refers to multi-level governance, i.e. the inter-relations that link stakeholders operating at various territorial levels (European, national, regional, local) [Hughes, Sasse and Gordon]. It can be defined as a process of joint decision-making between various government levels. In that sense, the multi-level governance concept signifies the significant transformation of public action. It involves designing new devices for coordinating stakeholders, networks and institutions in order to meet public action challenges. This new form of territorial governance can be seen as a system of interdependence and interaction between various stakeholders (EU institutions, central governments, local self-governments, etc.). Central government retains considerable manoeuvring room in these interactions, whereas regional self-governments, local representatives, non-governmental organisations, and enterprises are still staking out their place in the political reshaping process, thereby redefining power relations between the central and territorial levels. While the planning and management of LEADER embrace local decision-making and participation, programmatic evaluation is highly centralised and is held at arms length from the beneficiaries.

The new form of territorial governance comprises an arena, standards and stakeholders [Lascoumes and Le Galès. 2007]. The arena, in other words the forum for consultation, comprises institutions and networks, processes of coordination and interdependence, and horizontal forms of interaction between stakeholders. The standards refer to the principles for action, directives, rules and political and social practice. New principles underpin territorial development policy on a European scale: partnership, and selective targets at the local level (territorialisation). The change in standards introduced by political decentralisation and reform of public administration raises new challenges for local self-government. One example is the requirement for citizens' participation. This form of governance involves an increasing number of public and private stakeholders, groups whose boundaries are less clear-cut than before. The formal distinction between the different categories of stakeholders - municipalities (represented by their elected officials and development managers), non-profit associations (NGOs) and economic stakeholders (entrepreneurs, farmers) - is not entirely relevant. What are the consequences of implementing the EU-LEADER programme within existing political and social arrangements? Do they have positive and relevant effects on the consolidation of local democracy, such as the degree of civic participation at the community level? Do they comply with the European rules on accountability and transparency for public spending?

The second part of this article examines how the LEADER+ approach has been implemented in three Central European countries, with the aim of understanding its effects on the configuration of consultation forums (social arena) and the way local stakeholders are involved in 'social learning'. 
Experience with the LEADER programme in Central Europe (2004-2006): a common agenda, but differing ways and speeds of introducing it

Although the European Commission has laid out a common agenda for all new members, the introduction of the programme has been entrusted in each country to a single central decision-maker, the Ministry of Agriculture and Rural Development (MARD). As the LEADER programme's management body, this ministry initiates the setting up of the normative framework, namely the principles, rules and eligibility criteria. It is responsible for evaluation procedures and the ultimate selection of LAG (Local Action Group) according the quality of their 'business plan' and projects.

\section{Hungary: pragmatic implementation}

Hungary acquired its first experience with rural development under the premembership programmes (PHARE and then SAPARD) [Kukorelli Szörenyine 2005]. Even before it joined the European Union, an experimental programme on the LEADER model was launched in 2001, which laid the basis for preparing the paperwork, for setting up procedures and building pilot programmes. Fourteen LAGs were formed, with a total budget of $€ 1.7$ million. The LAGs were intended to adopt local rural development plans to address three types of action: aid for large families, the integration of Roma in local society, and youth training.

The LEADER+ measure came into force immediately after enlargement and was included in the Operational Programme for Agriculture and Rural Development (2004-2006), with a budget of $€ 19$ million ( $€ 14.3$ million of which from the European Union). A monitoring committee was set up in July 2004 and the programme began in 2005. The LAGs were selected following two calls for applications $(2005,2006)$. Initially programme implementation was due to involve fifty or so LAGs, but ultimately 67 were approved. The implementation of local strategies began in 2006. A national coordinating unit (the Agricultural and Rural Development Agency) was formed and operates via agencies in each county. The support networks for the development of rural areas are linked to the Secretariat for Rural Development under MARD. These include the National Rural Development Unit (a research centre of the RD Department), the Rural and Regional Development Offices (which are de-concentrated organs), and micro-regional rural development managers supported and trained by MARD and the RD Department.

LEADER+ is managed by a highly centralised system: application rules are defined by the Ministry of Agriculture and Rural Development, which operates in a manner thought by some observers to be overly directive. Because the LEADER+ programme is funded by the European Agricultural and Guarantee Fund (EAGF), it is under the responsibility of MARD, which provides a regulatory framework. Since MARD draws up a national rural development strategy, it directs general objectives and influences project orientation. Furthermore, it is 
responsible for evaluating and selecting projects and it monitors the allocation of funds by the Ministry of Finance, which is the payment authority. Project selection is the subject of hard bargaining. Evaluation criteria include, in addition to project relevance, the administrative capacity-building and experience that the LAG has acquired in managing public funds. In practice, other assessment factors, of a basically political nature (support from a party belonging to the political majority) affect the final decision to create or refuse to recognise a LAG.

\section{The Czech Republic: a flood of initiatives}

In the Czech Republic, the boom in public policies for rural areas goes back a long way, with, for example, the Rural Renewal Programme launched in 1991, which is still operating. A number of programmes during the past decade have concerned rural areas: the Rural Renewal Programme, the SAPARD Programme (2000-2004), and the Rural Development Operational Programme (2004-2006). The Rural Renewal Programme, which has supported micro-region training and projects, provides a sound base of experience for developing LEADER+. It runs the Best Village of the Year competition. Selected villages receive funds to carry out projects they have presented. The villages compete to propose ideas and advance pilot projects and infrastructure improvements at the inter-communal level.

Implementation of the LEADER programme was planned as early as 2001. Since 2004, the LEADER+ version has been the subject of a sub-measure on rural development and multifunctional agriculture within the Operational Programme. Co-funded by the European Agricultural Guidance and Guarantee Fund (EAGGF), this measure has a budget of $€ 5$ million to implement the strategy and $€ 1.53$ million for capacity building (i.e. training plans). As in Hungary, the LEADER+ programme is administered by the Ministry of Agriculture, which has a relatively narrow view and is mainly interested in farming issues. The Ministry of Agriculture is the main decision-maker on LAG applications.

In compliance with the approved Operational Programme, ten LAGs were selected in late December 2004 from the thirty applications submitted, and the funds for implementing the development strategies were allocated for a threeyear period. Each LAG must cover a territory with a population of between 10000 and 100000 and support between two and five projects, of which at least one must involve agricultural development. Within this measure, LAG may receive support for operating activities pursued in connection with the implementation of a LEADER strategic plan. LAG development strategies include improving the quality of life in rural areas, support for the business environment, added value for local products and better use of natural and cultural resources. Eligible project beneficiaries may be an individual person or companies in the farming and forestry sector, non-profit associations, and municipalities or a set of municipalities. 
The Ministry of Agriculture is also responsible for the LEADER CZ (Czech LEADER) programme. This is a set of measures identical to the above, operating according to LEADER principles and methods. In an annual call for applications the LAGs bid for fairly small projects (approximately Czk $3.5 \mathrm{~m}$ ). The Ministry of Agriculture approves a number of projects each year within its allocated budget. The Czech LEADER programme is the only one to support micro-regional cooperation between territories. In 2004, 121 applications for recognition as LAGs were received and 31 were selected with a total budget of Czk 77 million (Czk 28 = Eur 1). In 2005, 41 applications were received and 21 selected, with a total budget of Czk 70 million. In 2006, 64 applications were filed and 23 selected, also with a total budget of Czk 70 million. These LAGs have provided finance for 283 projects (of which 131 were for agricultural enterprises, 121 for municipalities, and 31 for non-profit associations).

A total of 75 LAGs have been selected in the Czech Republic for both programmes. They vary in size from very small projects, on a territory with around 10000 inhabitants, to a few really large ones (three of them are for territories with around 90000 inhabitants), and most are for territories with between 10000 and 25000 inhabitants. They satisfied the requirements for being included under the LEADER programme for the period between 2007 and 2013. In the future, Ministry of Agriculture officials would like to see the development of a median size project, for between 40000 and 50000 inhabitants. In terms of the involvement of local stakeholders, there are wide variations between regions. Southern Bohemia is highly active, with the most LAGs. The Olomouc and Liberec regions are also active. In Central Bohemia, there is a difference between Greater Prague, with its strong urban influence on micro-regions, and the rest. The Pardubice, Vysočina, and Brno regions are less active.

\section{Poland: no great hurry from the central authorities}

The Ministry of Agriculture and Rural Development is responsible for defining and implementing the LEADER+ pilot programme, which is a measure of the Operational Programme for agriculture and rural development. It is supported in this mission by the national network unit, the Foundation of Assistance Programmes for Agriculture (FAPA), which is responsible for receiving and processing application forms and formally verifying projects, and the payment authority is the Agency for Restructuring and Modernisation of Agriculture (ARMA), which disburses funds after approval from FAPA. Upstream, the Polish Rural Forum participates in preparing rural territories. A number of other institutions provide support, information or advice for rural communities.

The LEADER+ pilot programme has been implemented in two stages, known as schemes. Scheme I has the objective of the helping local communities acquire skills. It began with a call for applications in autumn 2004 and closed at 
the end of the calendar year. It involves support for training and advisory courses to promote the involvement of stakeholders with a view to analysing the potential development of territories and devising integrated development strategies. Under Scheme I, 167 LAG projects were selected in July 2005 ( $€ 5.8$ million). The Scheme II call for applications closed in mid-June 2006. Its role is to provide funding to implement development strategies. The formal procedure for selecting 80 LAGs took place throughout 2006. The call for applications was published on 31 March 2006 and closed in mid-June, with final selection in mid-October 2006. Consequently, the application and selection process ran late and it was not until January 2007 that the first contracts were signed between FAPA and the selected LAGs.

This brief presentation of the initial experiences countries had with implementing LEADER programmes reveals a number of common features: the preponderant role of the Ministry of Agriculture as the managing authority in administering the implementation process, the constraints of the eligible criteria system, the lack of transparency in the selection process, and the slowness in evaluating, selecting and funding the development projects proposed by LAGs.

\section{Assessing first outcomes}

\section{Social learning in rural communities}

The outcome of experimentation with the LEADER programme at the community level is not just about the introduction of a new approach to endogenous development; it can also be seen as a process of learning a new form of governance. This raises a number of questions about the choice of a new local development model, the ways of trying it out, and the extent to which it is accepted by local stakeholders. These points are examined here.

The concept of social learning can be considered relevant for the following specific reasons [High and Nemes 2007]. Social learning can take various forms: the acquisition of knowledge and skills, and the adoption and implementation of new rules for action and procedures. When learning is inspired by an existing model (as with the LEADER approach), this supposes a certain ability to receive and accept on the part of the learner. Learners who buy into the endogenous development model will draw from their own experience resources enabling them to adapt to new ways of operating. They move forward by trial and error. These two distinct cognitive mechanisms are not exclusive and can be combined, so that successful trials, and also errors, play a decisive role in the final result of the institutional model transfer.

It is a novel experience to learn an approach where the social stakeholders do not know the 'user's instructions' from the outset. Learning about the LEADER procedures requires an ability to understand the new principles and ways of 
acting. It is not enough for them to comply with the directives and rules enacted by central government; they have to build their own development. A political and social project of this kind invites all the stakeholders to modify their ways of thinking and practices of action. For elected officials, this change requires becoming aware of exercising responsibilities of a new type with respect to their fellow citizens and agreeing to be accountable for their actions. For rural community members, their involvement in local social life requires a civic commitment. The stakeholders' ability to buy into these changes comes at the cost of adapting their past behaviour. The formation of a LAG challenges the stakeholders' ability to involve themselves in designing strategies and building new projects. Within what is clearly a process of trial and error, the field research focused on the ability to mobilise the most dynamic elements in local society. This learning process and the forms it takes advance at varying rates according to the local political and social arrangements.

\section{Partnerships forming LAGs}

How does information reach the thousands of local communities in these three countries? To transmit basic information to the self-governments, the central administration has set up coordination units and contact points. It has also made use of a number of networks, such as for delegated bodies (county offices in Hungary), local authorities (voivodeship, kraj), foundations and NGOs specialising in organising rural areas (Rural Forum, PREPARE in Poland, the Centre for Community Organising in the Czech Republic), regional development agencies (in the Czech Republic), etc. These various institutions played an important role in the transmission of information about the LEADER approach. Internet access is crucial (the municipality needs to be connected and staff delegated to follow up on this type of information). This is not the case in all rural communities, especially in Poland.

The acquisition of skills focuses on a new discourse, which uses the same technocratic words and expressions as in European circles. At the meetings held by administrations or NGOs, in brochures and on websites, a new vocabulary of 'LEADER speech' (largely impenetrable for lay people) began to slip into the speech of local experts. Here is some information from the Hungarian case:

The Ministry of Agriculture has set up two-day training courses to inform mayors, entrepreneurs and associations about the operation of European programmes. One or two experts in each county were responsible for arranging these courses. The training budget was considerable but had to be spent on holding courses by the end of 2005. In the opinion of an employee working in Baranya county office, 'the country's administration does not fully understand the concept and philosophy of LEADER programmes'. In Baranya County, which comprise over 300 municipalities, 130 people attended an initial one-day session that was a precondition for the 
entire training course. The session was designed to explain LEADER regulations and how to form a LAG. Attendees were mayors, heads of business organisations, a few entrepreneurs, micro-regional managers, and representatives of chambers of agriculture and cooperative farms. The session first presented the philosophy of the LEADER programme in broad terms, and then case studies on preparing strategy based on examples in Hungary, the Netherlands and France. To use up the HUF 4.5-million budget, LAGs were created (before 30 August 2005). The county office's role was limited in this process. Its only role was to inform and coordinate. The Ministry of Agriculture kept control of the process and funding. Following the training sessions, twelve LEADER project applications were filed in the county. (Discussion with the employee responsible for the LEADER programme at the county office. Field research, Pécs, September 2006.)

The identity of the project designers and the reasons for local partnerships provide instructive evidence. From a formal point of view, Local Action Groups may be formed at the initiative of local self-governments (represented by their elected officials), or enterprises, or non-profit associations and non-governmental organisations. In practice, operations to form LAGs have almost exclusively been led by local elected officials (mayors), and the trigger event has usually been the announcement of LEADER funding. In most cases observed, the catalyst was the impetus given by a mayor, firmly based in his or her municipality within a network of local personalities at the micro-regional level. After the initial phase of forming partnerships ${ }^{3}$, the stakeholders began to design the project for their LAG. The strategies are connected either with the infrastructure in the area concerned, or with the development of a business plan for a particular economic activity, or with cultural projects of an identity-affirming nature, intended to enhance the attractiveness of a place. The strategy documents may be directly devised by the local project stakeholders, effectively or ineffectively helped along by development 'managers', or designed by paid consultancy offices or development agencies. The latter approach to preparing grant applications produces 'turnkey' recipes for unoriginal, one-size-fits-all projects. In such cases, the real purpose of the LEADER approach, namely innovation, strategic thinking and the awareness of community well-being, is absent. The transfer of this model, entrusted to project preparation professionals, runs the risk of copy-cat behaviour and a uniformity of strategic thinking in rural communities. As elected officials comply with directives to meet eligibility criteria and enhance their chances, the managers make use of conceptual window-dressing to transmit the local development approach. The LEADER rules are perceived as a new 'grammar' that just has to be learnt. The unoriginal nature of some projects reflects a lack of critical thinking.

\footnotetext{
${ }^{3}$ We do not examine further the question of the LAGs' choice of legal status, which has been settled in various ways according to each country's regulations (non-profit associations in Poland, consortium agreement managed by municipal services in Hungary, a civic association (o.s.) in the Czech Republic).
} 


\section{Territorial coverage by the LAG network}

The EU has laid down the criteria of size, population density and low urbanisation for rural areas to be eligible, and these have been complied with. A LAG must cover a population of between 10000 and 100000 and form a homogenous unit in physical, geographical, social and economic terms. The size and shape of LAG areas (the number of inhabitants, the share of rural population) vary according to the specific aspects of rural settlement patterns and administrative divisions in each of the three countries. LAGs cover a limited number of municipalities in Poland, where basic administrative units are large, sometimes ten or more in parts of Hungary (South Transdanubia), and there are several dozen of them in the Czech Republic, where the municipalities are very small. They are defined on the basis of a voluntary association of municipalities that have agreed to join. Because of unequal population density, any comment on the geographic coverage of each country must be cautious. It should not be seen as a fair reflection of the ability of local stakeholders to get involved in local actions according to the level of socioeconomic development in rural communities, at least in Poland [Śpiewak 2007].

During this experimental phase, the central government did not act to impose an a priori administrative breakdown. LAGs can only include wholly bottom-level administrative units. Compliance with eligibility criteria led to the creation of groups of municipalities whose areas and boundaries do not always correspond to identity territories as perceived by local communities. The relevance of a LAG's boundaries reveals a concern for territorial (geographical) and cultural coherence. Project territories are defined by features of physical, economic, social and cultural homogeneity (the term used in France would be pays). What are the bases for the operation of these inter-municipal associations? They correspond to the scale of mutual recognition between rural communities. It is the network of operational inter-municipal cooperation (infrastructure, equipment) that in some sense determines the scope of their action. In the Czech Republic and in Hungary, inter-municipal cooperation at the micro-regional level was firmly supported by official policy. However, these policies are different. The micro-regional division of Hungarian territory was elaborated by the Statistical Office using a range of socio-economic criteria. In the Czech Republic, micro-regions result out of a more spontaneous process. Although the boundaries do in all cases follow those of bottom-level local authorities (LAU 2, formerly NUTS 5), they may differ from administrative and planning divisions (Hungarian microregions, Czech municipalities with extended administrative competence), either extending beyond them or overlapping. They may even cut across NUTS-3 divisions (e.g. Moravia). However, in Hungary the decision to set up new regional development councils at the micro-regional level from 2004 may be a block to the spontaneous process of inter-municipal association. In some cases, it may hinder the free development of partnerships. The political affiliation of elected officials and, more basically, their trust in each other, also play a relatively important role. It is interesting to note how the definition of 'relevant territory' (area) is justified 
by stakeholders. Most elected officials argue that local development is primarily a matter of collective action. The dominant model appears to be the territory seen as a form of socio-economic organisation based on common interests. This is the scale for projects to add value to resources by specifying assets and undertaking concrete projects.

\section{The mobilisation of elites}

Although municipalities were the chosen way of transmitting information from above, local authorities have not all been responsive. In general, it can be said that earlier experience (PHARE programmes) and existing inter-communal cooperation have laid solid foundations for the emergence of new projects. A young generation of local managers and design office consultants, mainly graduates with an understanding of English, has surfaced as an active vector in transmitting the new LEADER thinking. They have realised the value that European programmes represent for their future careers. These representatives (forming a closely-knit network) have acquired sound skills in preparing documents that formulate analyses and propose strategies.

Professional mayors, with their skills in local self-government, have been catalysts in this process. The typical profile of an initiator is a firmly established, 'charismatic LEADER', heading a relatively large municipality (small town or large village), who has formed a network of patronage relations with his or her opposite numbers in neighbouring municipalities. In Hungary, the political independence asserted by rural mayors often conceals partisan networks of patronage. The existence of social and spatial relationships patiently formed by a small rural centre can then lead to the formation of an LAG area.

In addition to local elected officials who become entrepreneurs of local development, the LEADER approach is open to participation from other interest groups, farmers and business people, civil society bodies (cultural, social, sporting associations). Because this approach is based on participation, it implies formulating new relationships between citizens and their representatives. This participation is usually limited to meetings, somewhat pompously known as 'forums', which only a small number of initiates attend for debate. Local society is not greatly mobilised. When a local opinion survey is carried out, it is done by a company specialising in opinion polls, and the small number of respondents means that the sample size is smaller. The circle of stakeholders involved is small, made up of a few groups around elected officials, who know and support each other. Most of them are mayors, who see themselves as entrepreneurs of local development, determined to revive the economic and social base and encourage job creation. There are few associations or NGOs, and few business leaders or farmers. In LAG projects, the latter are usually mentioned as potential beneficiaries rather than as the sponsors of a genuine development strategy. They may 
be connected to elected officials through family or personal ties. The number of representatives from the third sector remains low and their participation largely superficial.

In the gmina of Korfantów (Opole voivodeship), the mayor (burmistrz), who has headed the municipal administration since 1982, helped by a staff member who was a specialist in the former state farm, responded rapidly to the Scheme I call for applications, offering to hold workshops in villages to provide information about local farm produce, organic farming and agri-tourism for smallholders. Advertising hoardings were used to inform the residents of the 24 settlements in the municipality. Final implementation of Scheme I was marked by a conference, to which were invited political personalities, the voivodeship marshal, members of parliament and members of the Odnowa Wsi (Revival of Rural Areas) foundation. By May 2006, the municipality had completely fulfilled the contract it had signed with FAPA, in charge of the LEADER programme, and had initiated an enlargement of the previous partnership. In order to apply more successfully to the Scheme II call, in May 2006, a new LAG was set up involving the neighbouring municipality of Prudnik and including a number of stakeholders belonging to the civic sector (for example Stowarzyszenie-Fundacja im. ks Kudelki) and to the business sector. A short time later, this new partnership, Stowarzyszenia Wspólne Źródła - Partnerstwo Obszarów Wiejskich Gmin Korfantów i Prudnik (Partnership for the rural areas of Korfantów and Prudnik municipalities), had became more independent from the mayor and it appears to be a kind of opponent group to the local power and its authoritarian practices, able to threaten him during the local elections in autumn 2006. (Field research in the gmina of Korfantów, 2006-2007)

In theory a LAG is a decision-making entity, but at this stage of field research it would be premature to describe its method of operation (how do they really work?). The reason is that the late assessment of applications for funding and subsequent allocation of funds by the payment authorities delayed the distribution of funds to the projects put forward by local stakeholders (companies, associations and municipalities). In the Úhlava ekoregion (Southern Bohemia) it appears that mayors played a key role in this negotiating process, seeking to distribute LEADER benefits fairly throughout the territory. In the Hátarmenti LAG (South Transdanubia, Baranya county), funding is concentrated in companies that have sponsored the implementation of the economic development strategy.

The success of LAG projects also depends on the lobbying abilities of local elected officials and their membership of partisan networks. To take only the case of Hungary: in Baranya County, the strong social democratic lobby (the MSzP, the party in government) is the explanation for the effective integration of LAG projects in the LEADER programme, and in other development projects. This observation raises the issue of clientelism (or 'dependency relationships'). According to the President of the LAG consortium of Keleti-Mecsek in Baranya County, whose application was selected in 2006, 'the regulations are not very clear about 
project selection; informal relations are crucial and no one is guaranteed to win on merit'. He adds: 'Most of the LAGs in the Mescek mountains area are homogeneous; the mayors are officially "independent", but they all lean towards the $\mathrm{MSzP}^{\prime}$. It is above all the political clout of the constituency member of parliament that matters. This Hungarian Socialist Party personality makes no secret of his ability to influence events. Similarly, the Minister of Agriculture comes from South Transdanubia, where he once worked as the director of a cooperative farm. His photo, a brief address, and his signature feature in the glossy colour brochure that presents the Hátarmenti LAG. In the Hungarian context, the political control parties have over the civil service is a holdover from the communist period. This is particularly true of the MSzP, which wields effective power of selection in the appointment of 'managers' (micro-regional managers for rural development). The principles of multi-level governance are barely respected here. At the bottom of the power structure, local personalities control their political resource of being able to influence the rural electorate (constituency); at the county (megye) level, regional personalities act as intermediaries between their constituencies and the central administration, whose representatives are hired and fired according to the party in government.

In the light of these conditions, it is hardly surprising to note the lack of transparency in the procedures for evaluating the quality of strategies proposed by LAGs, regularly denounced by those whose applications have been refused. A further analysis of the evaluation procedure and membership of selection committees would be essential.

\section{Conclusion: What should the next step be?}

What are the effects of the transfer of the rural development model? This article only offers preliminary evidence supporting the assumption that the responsiveness of local communities shows significant cross-national variations between countries. But a few points can be made here:

The system that has been adopted causes a mimicry effect, which is generated by training courses, the definition of project eligibility standards, and the central managing authority's evaluation and selection procedures. These normative conditions explain the concerns of local stakeholders about complying with expectations (at the risk of merely parroting the jargon of the European institutions that help to propagate the LEADER model). These remarks also need to be tempered. The transfer of the model is accompanied by increased signs of European awareness. The twelve-starred blue flag and the LEADER logo displayed at the entrance to villages and on documents help to popularise the image of the EU, a powerful benefactor in the eyes of local elites and their constituency. This new marking out of public space is accompanied by an increasing sense of belonging to Europe. Most local officials are convinced of the interest to belong to EU. For 
them, this manna from the EU can help them build the infrastructure their municipalities need. This positive attitude is part of a new state of mind, which is not the least of the benefits of these operations.

It is not at all clear what the impact of funding inappropriate projects will be on rural areas whose economies are not sufficiently diversified. Some examples are the duplication of cycle paths, wine roads, and agri-tourism packages in villages that have neither the facilities nor proper access. For local elected officials, the good fortune of such funding from the EU can help them build the infrastructure their municipalities need. Although elected officials initiate the formation of LAGs, they are not the real designers of these local development strategies. The project managers hired to help devise projects influence the conceptual basis of a local development project.

Becoming new partners in territorial development, elected officials have not all broken away from traditional practices (favouritism, paternalism). The low level of citizens' participation, the formation of interest groups monopolising access to grants, and the action of consultancy offices and development agencies are worrying signs. The implementation of the LEADER approach has been entrusted to agriculture ministries still heavily influenced by previous interventionist practices and in the sway of powerful farm lobbies.

Rural communities learning the LEADER approach seems like an interesting response to Europeanisation which is presumed to be a top-down process: new member states can only download EU models and cannot upload their national preferences. In practice, there is a basic contradiction between the exercise of top-down power and the LEADER approach, which is theoretically based on a bottom-up movement supported by local stakeholders. A mode of territorial governance that grants the major clout to central government stakeholders may well place limits on the still fragile progress of local democracy.

Marie-Claude Maurel is the director of CEFRES (French Centre for Research in the Social Sciences) in Prague, Czech Republic. She received her Doctorat d'Etat from ParisSorbonne in 1978. Between 1970 and 1986, she was assistant professor and then associate professor in the Department of Geography of the University of Montpellier. Since 1986, she has been a professor of human geography. From 1997 to 2001, she was the director of the Division of Humanities and Social Sciences at the CNRS in Paris. In 2002, she was elected Directrice d'études at the Ecole des Hautes Etudes en Sciences Sociales. She was a senior research fellow in Budapest Collegium in 2005. 
Marie-Claude Maurel: Local Development Stakeholders and the European Model

\section{References}

Bruckmeier, K. 2000. 'LEADER in Germany and the Discourse of Autonomous Regional Development.' Sociologia Ruralis 40 (2): 219-227.

Commission of the European Communities. 1996. The Cork Declaration: A Living Countryside. Brussels: DGVI.

Halamska, M. 2005. Rozwój wiejski w Portugalii w latach 1986-2000. Wzór czy przestroga dla Polski? (Rural Development in Portugal in 1986-2000 A Model or a Warning for Poland?) Warsaw: IRWIR, PAN.

High, C. and G. Nemes. 2007. 'Social Learning in LEADER: Exogenous, Endogenous and Hybrid Evaluation in Rural Development. Sociologia Ruralis 47 (2): 103-119.

Hughes, J., G. Sasse and C. Gordon. 2001. 'Enlargement and Regionalization: The Europeanization of Local and Regional Governance in CEE States.' Pp. 145-177 in One Europe or Several? Interlocking Dimensions of European Integration, edited by $\mathrm{H}$. Wallace. Basingstoke: Palgrave.

Kovach, I. 2000. 'LEADER, a New Social Order and the Central-and East-European Countries.' Sociologia Ruralis 40 (2): 181-189.

Kovach, I. 2002. 'Leadership, Local Power and Rural Restructuring in Hungary.' Pp. 91-121 in Leadership, Local Power and Rural Restructuring in Contemporary Europe, edited by K. Halfacree, I. Kovach and R. Woodward. Aldershot, Burlington, Singapore, Sydney: Ashgate.

Kovach, I. and E. Kučerová. 2006. 'The Project Class in Central Europe: The Czech and Hungarian Cases.' Sociologia Ruralis 46 (1): 3-19.

Kukorelli Szörenyine, I. 2005. 'The Appearance and Role of Micro-Regional Co-operations in the Hungarian Spatial Development.' Geografický časopis 57 (3): 229-246.

Illner, M. 2003. 'Devolution of Government in the Ex-Communist Countries: Some Explanatory Frameworks.' Pp. 9-28 in Local Democracy in Post-Communist Europe, edited by H. Baldersheim, M. Illner and Hellmut Wollmann. Opladen: Leske+Budrich.

Lascoumes, P. and P. Le Galès. 2007. Sociologie de l'action publique. Paris: Armand Colin.

Matějů, P. and A. Vitásková. 2006. 'Interpersonal Trust and Mutually Beneficial Exchanges.' Sociologický časopis/Czech Sociological Review 42 (3): 493-516.

Maurel, M.-C. and M. Halamska. 2006. Démocratie et gouvernement local en Pologne. Paris: CNRS éditions.

Meyer-Sahling, J.-H. 2007. 'Héritages, concurrence entre les partis et gouvernance de la fonction publique dans la Hongrie postcommuniste.' Critique internationale 35: 51-68.

Nemes, G. 2005. 'The Politics of Rural Development in Europe.' Discussion Papers. Institute of Economics, Hungarian Academy of Sciences 5: 1-38.

Ray, C. 2000. 'The EU LEADER Programme: Rural Development Laboratory.' Sociologia Ruralis 40 (2): 163-172.

Śpiewak, R. 2007. 'Przyslość polskiej wsí w oczach wiejskich liderów.' (The Future of the Polish Countryside in the Mind of Rural Leaders) Wies i Rolnictwo 2: 128-149. 